These sites represent a large range extension from the south Yukon (Cody 1996, page 162) to the northern limit of the Boreal Forest. Harris (1998, page 269) previously listed it as being present at $\mathrm{km} \mathrm{161.7,} \mathrm{Robert} \mathrm{Campbell} \mathrm{Highway.}$ It's rarity needs to be verified.

\section{JUNCACEAE}

Juncus stygius Linnaeus ssp. americanus (Buch.) Hultn - YUKON. Thermokarst Mounds, South Fork, Blackstone River, Dempster Highway at $138^{\circ} 22^{\prime} \mathrm{W}$., 64²8'N., July 1987 (UAC 70257).

Cody (1996, page 190) previously reported it from the Keno Hill area, while Cody et al. (1998, page 305) found it at Coal River in the southeast Yukon.

\section{Literature Cited}

Cody, W. J. 1994. The flora of the Yukon Territory: Additions, range extensions and comments. Canadian Field-Naturalist 108: 428-476.

Cody, W. J. 1996. Flora of the Yukon Territory. NRC Research Press, Ottawa, Ontario, Canada. 643 pages.

Cody, W. J. 2000. Flora of the Yukon Territory. $2^{\text {nd }}$ Edition, NRC Research Press, Ottawa, Ontario, Canada. 669 pages.

Cody, W. J., C. E. Kennedy, and B. Bennett. 1998. New records of vascular plants in the Yukon Territory. Canadian Field-Naturalist 112: 289-328.

Cody, W. J., C. E. Kennedy, and B. Bennett. 2000. New records of vascular plants in the Territory II. Canadian Field-Naturalist 114: 417-443.

Cody, W. J., C. E. Kennedy, and B. Bennett. 2001. New records of vascular plants in the Yukon Territory III. Canadian Field-Naturalist 115: 301-322.
Cody, W. J., C. E. Kennedy, B. Bennett, and V. Loewan. 2002. New records of vascular plants in the Yukon Territory IV. Canadian Field-Naturalist 116: 446-474.

Cody, W. J., C. E. Kennedy, B. Bennett, and J. Staniforth. 2003. New records of vascular plants in the Yukon Territory IV. Canadian Field-Naturalist 117: 278-301.

Douglas, G. W., G. W. Argus, H. L. Dickson, and D. F. Brunton. 1981. The rare vascular plants of the Yukon. Syllogeus \#28. National Museums of Canada, Ottawa. 61 pages.

Flora of North America Editorial Commitee. 2002. Flora of North America 23. Oxford University Press, New York. 608 pages.

Harris, S. A. 1998. Effects of vegetation cover on soil heat flux in the southern Yukon Territory. Erdkunde 52: 265-285.

Harris, S. A. 2004. Source areas of North Cordilleran endemic flora: Evidence from Sheep and Outpost Mountains, Kluane National Park, Yukon Territory. Erdkunde 58: 62-81.

Hultén, E. 1968. Flora of Alaska and neighbouring Territories. Stanford University Press, Stanford. 1008 pages.

Moss, E. H. 1983. Flora of Alberta. $2^{\text {nd }}$ Edition, revised by John G. Packer. University of Toronto Press, Toronto. 687 pages.

Wahl, H. E., D. B. Fraser, A. C. Harvey, and J. B. Maxwell. 1987. Climate of Yukon. Climatological Studies \#40. Atmospherric Environment Service, Environment Canada. 323 pages.

Received 21 February 2002

Accepted 21 August 2004

\title{
"Ashkui" Vernal Ice-cover Phenomena and Their Ecological Role in Southern Labrador
}

\author{
Shauna M. Baillie ${ }^{1}$, Corinne D. Wilkerson ${ }^{2}$ and Tina L. Newbury ${ }^{3}$ \\ ${ }^{1}$ Biology Department, P.O. Box 5000, St. Francis Xavier University, Antigonish, Nova Scotia B2G 2W5; e-mail:: sbaillie@ \\ stfx.ca \\ ${ }^{2}$ Biology Department, Memorial University of Newfoundland, St. John’s, Newfoundland A1B 3X9; e-mail: r34cdw@mun.ca \\ ${ }^{3} 10$ Highland Avenue, Corner Brook, Newfoundland A2H 2Y5; e-mail: tinalnewbury@hotmail.com
}

Baillie, Shauna M., Corinne D. Wilkerson, and L. Tina Newbury. 2004. "Ashkui" vernal ice-cover phenomena and their ecological role in southern Labrador 2002. Canadian Field-Naturalist 118(2): 267-269.

This is the first documented incident of River Otter (Lutra canadensis) feeding on Common Goldeneye (Bucephala clangula) in a little studied region, southern Labrador. Our observations were made during spring staging when waterfowl aggregate at open water sites in frozen lakes and rivers, locally known as ashkui. We suggest that otters and raptors opportunistically forage on staging waterfowl at ashkui.

Key Words: River Otter, Lutra canadensis, Common Goldeneye, Bucephala, clangula, Bald Eagle, Haliaeetus leucocephalus, predator-prey interactions, staging waterfowl, ashkui, Labrador.

Ashkui (singular and plural form) is the Innu name given to sites of open water in river and lake systems within the frozen spring landscape of Labrador (Fletcher and Breeze 2000*). Migratory waterfowl, including Common Goldeneye (Bucephala clangula), use ashkui as staging areas enroute to their breeding grounds. These birds arrive in groups of tens to hundreds to rest and rebuild energy reserves by feeding on invertebrates, fish, seeds and other plant material at ashkui (Newbury 2002*). Beaver (Castor canadensis), River Otter (Lutra canadensis) and Muskrat (Ondatra zibethicus), have been observed at these sites. Osprey (Pandion haliaetus) and Bald Eagle (Haliaeetus leucocephalus) are known to fish at ashkui (Fletcher and Breeze 2000*). The temporal existence, number and distribution of ashkui sites are influenced by a high 
degree of inter-annual variability in the onset of spring thaw. As the winter snows disintegrate and waterfowl await availability of breeding habitat, they may be susceptible to predation. In 2002, the opening of ashkui occurred two weeks later than in previous years (unpublished data, Environment Canada, St. John's, Newfoundland).

Our observations were made during a study examining the effects of military low level flying on the behaviour of staging waterfowl at Lac Fourmont in southern Labrador $\left(52^{\circ} 00^{\prime} \mathrm{N}, 60^{\circ} 15^{\prime} \mathrm{W}\right.$; Newbury $\left.2004^{*}\right)$. While conducting waterfowl behavioural observations, we witnessed a River Otter feeding on a male Common Goldeneye. We also observed a Bald Eagle attack another goldeneye resting on the ice.

\section{Study Area}

Lac Fourmont is situated within the Boreal Forest Region of eastern Canada and is influenced by continental climatic regimes (Lopoukhine et al. 1977*). This region is covered with ice and snow until daily spring thaw temperatures rise to $5.1^{\circ} \mathrm{C}$ in May (30 year average for Goose Bay, Labrador; Environment Canada Meteorological Service, St. John's, Newfoundland). Daytime average temperatures were $4.1^{\circ} \mathrm{C}$ in May 2002 and ranged from 4.0 to $9.0^{\circ} \mathrm{C}$ for May during the years 1993 to 2002 . River width at the observation location was approximately $1 \mathrm{~km}$, and the $a s h k u i$ site was $20 \mathrm{~m}$ in breadth. Ice breadth from ashkui to shoreline was approximately $50 \mathrm{~m}$. Forest stands were composed of mainly Black Spruce (Picea mariana) and Balsam Fir (Abies balsamea) interspersed with approximately $10 \%$ Paper Birch (Betula papyrifera), Balsam Poplar (Populus balsamifera), and Trembling Aspen (Populus tremuloides). Lake-edge shrubs consisted of willows (Salix spp.) and alders (Alnus rugosa and $A$. crispa). River and bank substrate was composed of coarse-grained sand and pebbles with exposed boulders and bedrock of gneiss and mafic intrusions. River basin and landscape were low gradient with shallow sloping banks, wide flood plain and low relief hills.

We conducted daily observations on waterfowl behaviour from blinds using a Swarovski $60 \times$ spotting scope from 9:00 to $12: 00$ and 13:00 to $16: 00$ between 26 April and 27 May 2002. Also, we conducted thirteen random $1.5 \mathrm{~h}$ watches during dawn and dusk.

\section{Observations}

Fourteen species of waterfowl occupied the Lac Fourmont ashkui. Daily waterfowl numbers at the ashkui ranged from 34 to 376 during this study. A single River Otter was noted at the ashkui during at least five observation days. The number of sightings of mature and immature Bald Eagles, Osprey and Roughlegged Hawk (Buteo lagopus) totaled 7, 2, 1 and 1, respectively, over 8 non-consecutive study days.

On 6 May 2002 at 11:35, we observed a River Otter grasping a male Common Goldeneye on the ice, ap- proximately $70 \mathrm{~m}$ from our observation blind on the south side of the ashkui. Although the capture was not observed, the goldeneye was alive and struggling when the otter was initially observed. The otter sat on its rear haunches with the goldeneye braced in its forepaws and consumed the head of the duck first before eating the breast muscles and abdominal viscera. After approximately 10 minutes of feeding, the otter slipped into the water and swam downstream without the carcass remains. We did not observe the fate of the duck carcass, as it was no longer visible on the ice when the otter left the feeding site. The bird flock, during this observation period, comprised mainly 65 Common Goldeneyes, 27 Black Ducks, 113 Canada Geese (Branta canadensis).

On 18 May 2002 at 16:03, we observed a Bald Eagle circle the ashkui and plunge downward toward a small group of Common Goldeneyes resting and sleeping on the ice, approximately $150 \mathrm{~m}$ from our position. Upon impact, the eagle initially captured a goldeneye. The eagle then struggled with the goldeneye while standing on the ice edge but was unable to maintain its grasp. The goldeneye fell from the ice to the water then became inter-mixed with the flock. This interaction lasted approximately one minute and, we were unable to identify the attacked goldeneye after its escape. The eagle then flew to the other side of the ashkui and rested on the ice. The bird flock, during this observation, comprised mainly 7 Common Goldeneyes, 29 Black Ducks (Anas rubripes), 67 Canada Geese (Branta canadensis), 11 Greater Scaup (Aythya marila) and 20 Ring-necked Ducks (Aythya collards).

\section{Discussion}

Fish are often the main prey of River Otter and raptorial predators (Chubbs and Trimper 1998; Larivière and Walton 1998; Fletcher and Breeze 2000*; Heath et al. 2001; Jedrzejewska et al. 2001). Studies in the Great Lakes and North American boreal ecosystems have shown that the diet of River Otter comprises mostly fish (Larivière and Walton 1998). However, otters have been known to feed opportunistically on small mammals, molluscs, reptiles, birds and fruits (Larivière and Walton 1998). In west-central Idaho, otters supplemented their fish diet with invertebrates and reptiles (Melquist and Hornocker 1983). In Great Britain and Ireland, otters consume primarily fish, and lesser amounts of small mammals, medium-sized mammals, birds, herpetofauna, earthworms, other invertebrates and carrion of large mammals (McDonald 2002). Jedrzejewska et al. (2001) showed that otters specialize on prey taken from water. It is plausible that an otter fishing for fish under water may opportunistically capture diving goldeneyes. Although River Otters were known to occasionally feed on birds (Larivière and Walton 1998), we believe that this was the first documented case of an otter feeding on a Common Goldeneye. 
Instances of Bald Eagles preying on duck species are not rare (Jackman et al. 1999; Heath et al. 2001). Although fish dominate their diet, Bald Eagles have been reported to modify foraging behaviour and may forage opportunistically on staging waterfowl in situations where return on such effort makes them economical (Brown et al. 1998; Jackman et al. 1999).

The temporal existence, number and distribution of ashkui, in southern Labrador during spring, may influence the spatial and temporal distribution of piscivorous predators and migratory waterfowl by limiting the availability of open-water feeding and resting areas. Migratory waterfowl arriving from southern destinations must accumulate in greater concentrations when ashkui openings are limited. Though the behaviour and distribution of River Otter were not documented for Labrador, Larivière and Walton (1998) stated that otters made heavy use of ashkui in winter and "almost exclusively" used open water for locomotion and foraging (Madsen and Prang 2001; Ruiz-Olmo et al. 2001). Piscivorous raptors returning to breeding areas must travel to and congregate at available ashkui to fish. It was likely that spatial and temporal distribution of ashkui also affected predator-prey interactions.

Our observations are examples of opportunistic foraging events on waterfowl by predators that appear to use ashkui regardless of the presence of waterfowl. Further investigations in Labrador are needed to understand better the ecological importance of the temporal and spatial distribution of ashkui to mammalian and raptorial predators.

\section{Acknowledgments}

This project was funded in partnership by the Institute for Environmental Monitoring and Research (IEMR), the Canadian Wildlife Service (CWS), McGill University and the Department of National Defence (DND), and by the Northern Scientific Training Program. Many thanks to Sean Sharpe (IEMR), Tony Chubbs (DND) and Roger Titman (McGill University) for invaluable discussion, advice and/or informal manuscript review. Jean Sealy (CWS), Scott Gilliland (CWS) and Dawn Laing (DND) helped us with literature searches. Thanks to Keith Chaulk (CWS), Bruce Whiffen (Environment Canada) and Sarah Hall (CWS) for providing information on weather and ice conditions.

Documents Cited [marked $*$ in text]

Fletcher, C., and H. Breeze. 2000. Ashkui sites in the lowlevel flight training area, Labrador. Report prepared under contract to Institute for Environmental Monitoring and Research (I.E.M.R.). Gorsebrook Research Institute for Atlantic Canada Studies, Saint Mary's University, Halifax, Nova Scotia. 22 pages.

Lopoukhine, N., N. A. Prout, and H. E. Hirvonen. 1977. The ecological land classification of Labrador. Ecological Land Classification Series, Number 4. Fisheries and Environment Canada. Halifax, Nova Scotia.

Newbury, Tina L. 2002. Effect of low-level flights on the behaviour of spring staging waterfowl in Central Labrador. M.Sc. thesis Proposal. McGill University. Ste. Anne-deBellevue, Quebec, Canada.

Newbury, Tina L. 2004. Effect of low-level military jet overflights on the behaviour of spring-staging waterfowl at Lac Fourmont ashkui, Labrador, Canada. M.Sc. thesis. McGill University. Ste. Anne-de-Bellevue, Quebec, Canada.

\section{Literature Cited}

Brown, B. T., L. E. Stevens, and T. A. Yates. 1998. Influences of fluctuating riverflows on Bald Eagle foraging behaviour. Condor 100: 745-748.

Chubbs, Tony E., and Perry G. Trimper. 1998 The diet of nesting Ospreys, Pandion haliaetus, in Labrador. Canadian Field-Naturalist 112: 502-505.

Heath, Joel P., Geoff Goodyear, and Joe Brazil. 2001. Observation of a Golden Eagle, Aquila chrysaetos, attack on a Harlequin Duck, Histrionicus histrionicus, in northern Labrador. Canadian Field-Naturalist 115: 515-516.

Jackman, R. E., W. G. Hunt, J. M. Jenkins and P. J. Detrich. 1999. Prey of nesting bald eagles in northern California. Journal of Raptor Research 332: 87-96.

Jedrzejewska B., V. E. Sidorovich, M. M. Pikulik, and W. Jedrejewski. 2001. Feeding habits of the otter and the American mink in Bialowieza Primeval Forest (Poland) compared to other Eurasian populations. Ecography 242: 165-180.

Larivière. Serge, and Lyle R. Walton. 1998. Lutra canadensis. Mammalian Species (587) American Society of Mammalogists. Pages 1-8.

Madsen, A. B., and A. Prang. 2001 Habitat factors and the presence or absence of Otters Lutra lutra in Denmark. Acta Theriologica 46: 171-179.

McDonald, R. A. 2002. Resource partitioning among British and Irish mustelids. Journal of Animal Ecology 71: 185200.

Melquist, W. E. and M. G. Hornocker. 1983. Ecology of river otters in west central Idaho. Wildlife Monographs 83: 1-60.

Ruiz-Almo. J., J. M. Lopez-Martin, and S. Palazon. 2001. The influence of fish abundance on the otter (Lutra lutra) population in Iberian Mediterranean habitats. Journal of Zoology 254: 325-336.

Received 28 June 2002

Accepted 19 October 2004 